\title{
NZEB and market-based renovation case study of an existing office building
}

\author{
Helena Kuivjõgi ${ }^{* 1}$, Jarek Kurnitski ${ }^{2,3}$, Aivar Uutar $^{1}$ and Martin Thalfeldt ${ }^{1}$ \\ ${ }^{1}$ Tallinn University of Technology, Department of Civil Engineering and Architecture, Ehitajate tee 5, 19086, Tallinn, Estonia \\ ${ }^{2}$ Smart City Center of Excellence, Tallinn University of Technology, Ehitajate tee 5, 19086 Tallinn, Estonia \\ ${ }^{3}$ Aalto University, School of Engineering, Department of Civil and Structural Engineering, Finland
}

\begin{abstract}
The goal of decarbonizing the building stock in the EU requires a multi-fold increase of the current renovation rates. In Estonia, the non-residential building sector has had little or no public support to improve the energy efficiency. Therefore, it is essential to study the energy efficient and cost-optimal measures for non-residential building renovation to give guidance to real estate companies and other stakeholders about the renovation alternatives. Furthermore, crucial is to provide input to the government to develop the renovation grant and incentives for renovation. In this study, energy renovation measures and savings to improve the energy performance to NZEB level were identified in a large (16 $990 \mathrm{~m}^{2}$ heated area) office building. For that purpose, energy use was measured, simulation model developed and calibrated, feasible and more comprehensive energy improvements and costs analysed. The improvement of lighting, AHU, heating, installation of a $69 \mathrm{~kW}$ PV system, and window replacement was needed to achieve the goal with a primary energy use of $163 \mathrm{kWh} / \mathrm{m}^{2}$. However, some of the applied measures had long payback times of 40-70 years and are not realistic to be implemented without renovation incentives.
\end{abstract}

\section{Introduction}

European Union (EU) has a goal to develop a sustainable, competitive, secure, and decarbonised energy system in EU Member States by 2050. The purpose and guidelines are brought out in the energy performance (EP) of building directive (EPBD). [1]-[3] Further steps are to develop measures that reduce the final energy use of buildings to reduce greenhouse gas emissions. Non-residential buildings account for $25 \%$ $\left(\mathrm{m}^{2}\right)$ of the total stock in Europe and office buildings are the second biggest category (23\%). However, the specific energy use of non-residential buildings (covering all end-uses) is at least $40 \%$ greater than the equivalent value for the residential sector. [4], [5]

Energy use of a building is evaluated with the energy performance certificate (EPC) that indicates the EP of a building calculated by a methodology adopted in accordance with Directive 2010/31/EU [3]. In Estonia it is defined as primary energy (PE) and the limits from [6] are in Table 1. Regarding the standard ISO 52000-1 [7], to calculate the PE use and EPC of an existing buildings, the measured energy use can be used. However, the electricity for other uses than energy performance of buildings (non-EPB) (e.g., small power plug loads, commercial activities, elevators, industrial kitchen) should be excluded from calculation. Nevertheless, in Estonian regulation [6], [8] the appliances are included to the energy calculation. Therefore, as shown in [4] and [11], today major electricity uses in the office are not necessarily considered by long-term renovation strategies.

Estonian long-term renovation strategy states that today the annual PE use is $225-270 \mathrm{kWh} / \mathrm{m}^{2}$ (delivered heating $130 \mathrm{kWh} / \mathrm{m}^{2}$ and electricity $70 \mathrm{kWh} / \mathrm{m}^{2}$ ) in office buildings constructed before 2000. However, to achieve the major renovation NZEB level (class $\mathrm{C}$ in Table 1), the PE for an office building should be 136$160 \mathrm{kWh} / \mathrm{m}^{2}$ (delivered heating $70 \mathrm{kWh} / \mathrm{m}^{2}$, electricity $45 \mathrm{kWh} / \mathrm{m}^{2}$ ). Unfortunately, today building stock has several barriers that prevent to achieve the NZEB level renovation. One main barrier is the long, 20-30 year payback time of NZEB renovation, as real estate companies prefer the payback time around 10 years. [9]

Table 1. Primary energy limits of Energy Performance Certificate level in Estonia (EPBD scope without appliances)

\begin{tabular}{|c|c|c|}
\hline Class & Office, $\mathrm{kWh} / \mathrm{m}^{2}$ & Office EPBD scope, $\mathrm{kWh} / \mathrm{m}^{2}$ \\
\hline $\mathrm{A}^{1}$ & 100 & 62 \\
\hline $\mathrm{B}$ & 130 & 92 \\
\hline $\mathrm{C}^{2}$ & 160 & 122 \\
\hline $\mathrm{D}$ & 210 & 172 \\
\hline $\mathrm{E}$ & 260 & 222 \\
\hline
\end{tabular}

${ }^{1}$ NZEB for a new building

${ }^{2} \mathrm{NZEB}$ for major renovation

This study is a continuation and clarification of the article [9], that has contributed to Estonian long-term renovation strategy [11]. The idea is to give an overview of the measured energy consumption and analyse the energy renovation measures to improve the energy performance of NZEB major renovation in office buildings.

* Corresponding author: helena.kuivjogi@taltech.ee 


\section{Methods and materials}

\subsection{Reference building measured energy use}

The reference building (Figure 1) is actively used, well maintained, and with good ventilation system 5 storey office building with heated area $16990 \mathrm{~m}^{2}$ built in 2008. The construction has a deep foundation and non-loadbearing exterior walls (EW) (wood frame with mineral wool thickness $0,15-0,18 \mathrm{~m}$ ), external floor (EF) towards ambient air (concrete panel with wood frames and insulation thickness $0,25 \mathrm{~m}$ ), EF towards the ground (concrete floor with insulation in perimeter), roof (loadbearing profile plate and mineral wool plates or concrete panel with $0,18 \mathrm{~m}$ mineral wool and 0,05 m EPS 65F). Building has an uncommon shape and WWR about $50 \%$. We consider that the reference building has 3 elevators (one for each building section). On the first floor, the trade areas and canteen (respectively, $10 \%$ and $3 \%$ of the total area) are located, and the other floors are for offices (about $83 \%$ of the total area) and health care ( $5 \%$ of the total area). Heat supply comes from the local natural gas substation and electricity from the power grid.

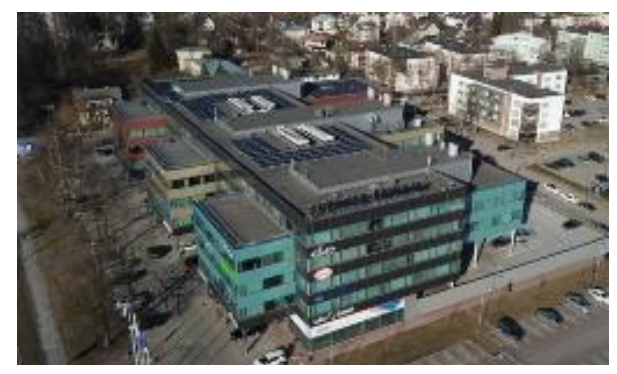

Figure 1. Reference office building built in 2008 (AU Energiateenus)

We collected the delivered energy of the reference building from the energy invoices measured by the main energy meters (look in Figure 2). Measured total delivered heating energy was $104 \mathrm{kWh} / \mathrm{m}^{2}$ and electricity $126 \mathrm{kWh} / \mathrm{m}^{2}$ (non-EPB included). Specific services were not measured, but assumed by calculations and other studies. Domestic cold water use was measured and the domestic hot water (DHW) percentage of this was assumed to be $40 \%$. Using this data, the DHW use was calculated by Equation 1:

Where

$$
Q_{D H W}=m \times C_{p} \times \rho \times \frac{\Delta T}{3600}
$$

\section{E: energy, kWh}

$\mathrm{m}$ : the mass of water, 1

$\mathrm{Cp}$ : specific heat of water, $\mathrm{kJ} / \mathrm{kg}{ }^{\circ} \mathrm{C}$

$\Delta \mathrm{T}$ : temperature difference, ${ }^{\circ} \mathrm{C}$

$\rho$ - density of water in $50^{\circ} \mathrm{C}$

DHW use was separated from heating energy use and the last one was weather normalized with degree day method. Table 2 shows the monthly weather normalized heating energy, domestic hot water (DHW) heating, and electricity energy use in the reference building in the years 2012-2014.
Table 2. Actual measured weather normalized energy use in the reference building

\begin{tabular}{|c|c|c|c|c|c|c|c|c|c|}
\hline & $\begin{array}{r}\text { venti } \\
k\end{array}$ & $\begin{array}{ll}l a \\
\text { L }\end{array}$ & at, & $\mathrm{DH}$ & 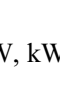 & & & & \\
\hline & 12 & 2013 & 2014 & 2012 & 2013 & 2014 & 2012 & 2013 & 201 \\
\hline & 16.6 & 15.6 & $\mid 14.7$ & 0.60 & 0.56 & 0.51 & 12.9 & 9.92 & 9.36 \\
\hline$b$ & 13.7 & 13.3 & 15.2 & 0.52 & 0.48 & 0.47 & 11.0 & 8.77 & 8.75 \\
\hline $\mathrm{ar}$ & 11.3 & & 12.1 & 0.57 & 0.46 & 0.89 & 11.5 & 61 & 9.33 \\
\hline $\mathrm{pr}$ & 7.94 & 7.93 & 8.01 & 0.53 & 0.50 & 0.53 & 10.9 & 8.75 & 9.75 \\
\hline ay & 5.02 & 3.77 & 4.28 & 0.59 & 0.59 & 0.56 & 11.5 & 9.77 & 11.2 \\
\hline in & 2.11 & 2.78 & 2.04 & 0.54 & 0.50 & 0.67 & 11.6 & 10.1 & 11.0 \\
\hline al & 2.78 & 1.68 & 3.01 & 0.43 & 0.59 & 0.58 & 10.8 & 10.8 & 13.7 \\
\hline ug & 2.03 & 2.00 & 2.27 & 0.47 & 0.42 & 0.58 & 10.6 & 12.1 & 12.5 \\
\hline $\mathrm{ep}$ & 4.61 & 4.96 & 4.92 & 0.57 & 0.50 & 0.57 & 9.8 & 11.2 & 11.4 \\
\hline & 6.92 & 8.23 & 7.42 & 0.49 & 0. & 0.76 & 11.1 & 10.8 & 11.1 \\
\hline $\mathrm{ov}$ & 10.9 & 12.1 & 11.0 & 0.55 & 0.50 & 0.59 & 9.7 & 10.0 & 9.9 \\
\hline ec & 12.2 & 16.0 & 14.8 & 0.42 & 0.52 & 0.61 & 9.0 & \begin{tabular}{|l|l}
9 & 9.6
\end{tabular} & 10.0 \\
\hline
\end{tabular}

The specific electricity for non-EPB use (Figure 2) has been estimated by further calculations. Cooling electricity and plug load electricity for the server room has been calculated by the installed power of fan coils in server room. This building has 18 electrical service or server rooms that are cooled by fan coils with different cooling power: $1 \mathrm{~kW}$ to $4 \mathrm{~kW}$. The sum of fan coil cooling power is about $61 \mathrm{~kW}$ and it was assumed that the servers will work every day all over the year $(8760 \mathrm{~h})$. Annual cooling power is about $31 \mathrm{kWh} / \mathrm{m}^{2}$. The SEER of chiller has been taken 3.5 and therefore, the electricity use is $9 \mathrm{kWh} / \mathrm{m}^{2}$. Outdoor lighting is fluorescent lights with bulb power $58 \mathrm{~W}$. As there are about 25 lights, the annual electricity energy for outdoor lighting was $6.2 \mathrm{MWh}\left(0.36 \mathrm{kWh} / \mathrm{m}^{2}\right)$. The electricity of the 3 lifts was about $13 \mathrm{kWh} / \mathrm{m}^{2}$, estimated by the study [12].

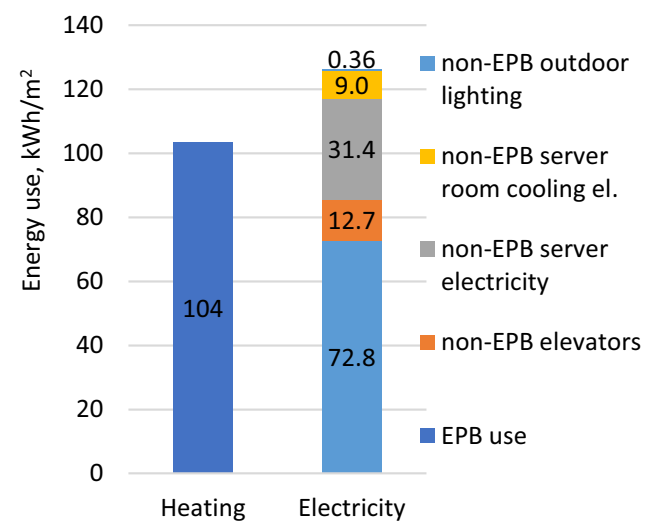

Figure 2. Energy use in the reference building

\subsection{Energy simulation model}

For further analyses, there was built an energy simulation model (further as the base model) of the reference building (Figure 3) in the energy and indoor climate simulation program IDA Indoor Climate and Energy 4.8 (IDA-ICE) by using project documentation and energy audit information. The test reference year of Estonia was used [13]. 


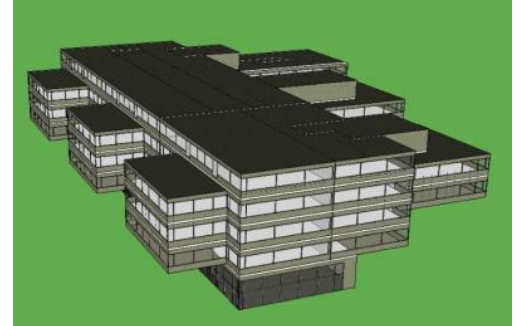

Figure 3. IDA-ICE model of the reference building Table 3 represents the input data of the base model. In the calculation of heating energy use, the generation and distribution were considered with heat source efficiency factor and efficiency factor of the distribution and output of radiator (

Table 3). For cooling calculation, there was taken into account also the heat loss coefficient and Eq. 2 was used from [8].

where

$$
Q_{j}=\left(1+\beta_{j e}\right) Q_{j e}\left(1+\beta_{r s}\right) Q_{r s}
$$

$\mathrm{Q}_{\mathrm{je}}$ - annual net energy of AHU cooling elements $\mathrm{kWh}$; $\mathrm{Q}_{\mathrm{rs}}$ - annual net energy of zone units kWh;

$\beta_{\mathrm{je}}-$ the energy loss associated with AHU cooling elements

$\beta_{\text {rs }}$ - the energy loss of cooling energy distribution to zone

Base model imitates the real performance of the reference building and has occupancy, appliances, lighting, and AHU schedules according to real use (in Appendix 1, Figure 9-Figure 14).

Finally, the delivered energy has been correlated with primary energy factors as for natural gas 1.0 and for electricity 2.0 to calculate the PE.

Table 3. Input data of the base model and for energy use calculations

\begin{tabular}{|l|c|}
\hline Occupants. $\mathrm{m}^{2}$ per occupant & 17 \\
\hline Equipment. W/m² (average, office/trade) & $12 / 1$ \\
\hline Lightning. W/m² (average, office/trade) & $10 / 12$ \\
\hline Temperature setpoint for heating. ${ }^{\circ} \mathrm{C}$ & 21 \\
\hline Temperature setpoint for cooling. ${ }^{\circ} \mathrm{C}$ & 24 \\
\hline Air flow rate. $1 /\left(\mathrm{s} \mathrm{m}^{2}\right.$ ) (average) & 1.7 \\
\hline Heating system (radiators) efficiency. - & 0.97 \\
\hline Heat source (gas) efficiency. - & 0.95 \\
\hline AHU fans SFP $\mathrm{kW} /\left(\mathrm{m}^{3} / \mathrm{s}\right)$ & $1.1-1.9$ \\
\hline SEER of chiller. - & 3.5 \\
\hline Ventilation heat exchanger efficiency, - & $0.7 / 0.4$ \\
\hline Annual DHW consumption. $1 / \mathrm{m}^{2}$ & 103 \\
\hline Average U-value of model, $\mathrm{W} /\left(\mathrm{m}^{2} \mathrm{~K}\right)$ & 0.38 \\
\hline SFP - specific fan power. & \\
\hline
\end{tabular}

\subsection{Calibration method of energy simulation model}

Energy simulation model has been calibrated with the corresponding and normalized energy use of the reference building (Table 2), both data for year 2014 .

The calibration was done and the modelling uncertainty was controlled by the coefficient of variation of root mean square error (CV(RMSE)) Eq. 3, (regarding to ASHRAE Guideline [14]) which indicates the uncertainty inherent in the model and the computer model shall have a $\mathrm{CV}(\mathrm{RMSE})$ of $15 \%$ relative to the monthly calibration data. Results are in Table 4.

CVRMSE $=100 \times\left[\sum\left(y_{i}-\hat{y}_{i}\right)^{2} /(n-p)\right]^{1 / 2} / \bar{y}$

The energy performance simulation in standard condition was done to calculate the energy performance certificate (EPC) and clarify whether the measures achieve the level of NZEB major renovation. The base model according to standard conditions uses the schedule in Appendix 1, Figure 9, every zone for occupancy, appliances and lighting (except in the trade area, where the lighting and appliances schedule is 0.55 at 7-21:00). The AHU works in full capacity from 6:00 to $19: 00$ and outside these hours is set to work $7.5 \%$ of the total capacity.

\subsection{Improvement of energy performance}

Several energy saving measures have already been implemented in this building. However, the improvement of automatics, rebuilding of the cooling system, improvement of free cooling of ventilation and cooling system did not achieve the NZEB level of this building regarding to energy audit. Furthermore, there has been constructed the combined heat and power (CHP) station and the photovoltaic (PV) panel system. Arithmetical calculation shows that these savings will achieve the C-level of this building, but needs further detailed investigation.

Table 4. Calibrated data and uncertainty of energy simulation model (measured and simulated results are for year 2014)

\begin{tabular}{|c|c|c|c|c|c|c|c|}
\hline \multirow{2}{*}{$\begin{array}{c}\text { Measured, } \\
\mathrm{kWh} / \mathrm{m}^{2}\end{array}$} & \multicolumn{2}{|c}{$\begin{array}{c}\text { Simulated, } \\
\mathrm{kWh} / \mathrm{m}^{2}\end{array}$} & \multicolumn{2}{c|}{ RMSE } & \multicolumn{2}{c|}{ NMBE } \\
\cline { 7 - 10 } & & \multicolumn{2}{c}{ Heat. } & Electr. & Heat. & Electr. \\
\hline Heat. & Electr. & Heat. & Electr. & & & & \\
\hline 15.2 & 4.82 & 15.5 & 6.06 & 0.09 & 1.54 & -0.30 & -1.24 \\
\hline 15.7 & 4.65 & 15.1 & 5.33 & 0.37 & 0.47 & 0.61 & -0.68 \\
\hline 13.0 & 4.80 & 11.9 & 5.77 & 1.10 & 0.95 & 1.05 & -0.97 \\
\hline 8.54 & 5.36 & 8.11 & 5.91 & 0.18 & 0.30 & 0.43 & -0.55 \\
\hline 4.84 & 6.63 & 5.80 & 6.61 & 0.92 & 0.00 & -0.96 & 0.02 \\
\hline 2.71 & 6.57 & 3.45 & 6.55 & 0.55 & 0.00 & -0.74 & 0.01 \\
\hline 3.59 & 9.12 & 1.41 & 8.32 & 4.76 & 0.64 & 2.18 & 0.80 \\
\hline 2.85 & 7.97 & 2.50 & 7.04 & 0.12 & 0.87 & 0.35 & 0.93 \\
\hline 5.48 & 6.98 & 3.74 & 6.05 & 3.05 & 0.88 & 1.75 & 0.94 \\
\hline 8.17 & 6.59 & 7.79 & 6.09 & 0.15 & 0.24 & 0.39 & 0.49 \\
\hline 11.6 & 5.48 & 12.8 & 5.48 & 1.41 & 0.00 & -1.19 & 0.00 \\
\hline 15.4 & 5.43 & 15.2 & 6.06 & 0.05 & 0.39 & 0.21 & -0.62 \\
\hline & & & CV> & $\mathbf{1 2 \%}$ & $\mathbf{1 2 \%}$ & $\mathbf{3 . 8 \%}$ & $\mathbf{- 0 . 9 \%}$ \\
\hline
\end{tabular}

This study was considering different measures to increase the energy use and achieve the C-level of the reference building. Several measures were selected by the suggestion of energy audits, the knowledge of the authors, and measures earlier studied in [9] were improved.

The measures were added to the base model individually (method described in Figure 4) and the saving of every measure has been calculated with the energy simulation software IDA-ICE 4.8. 


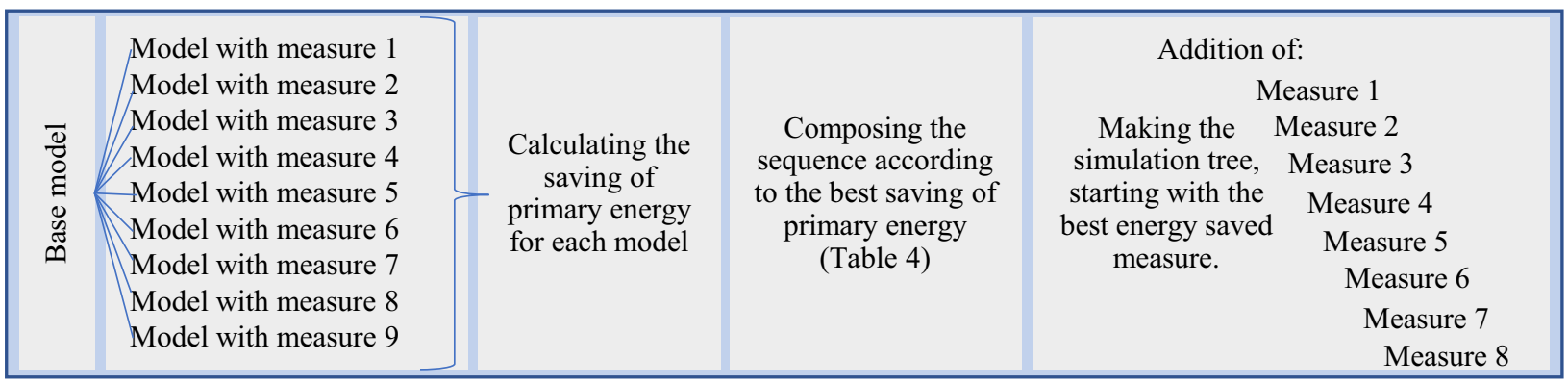

Figure 4. Methodology to compose the energy saving packages

Furthermore, the sequence of measures regarding the best saving of primary energy was composed and the models with measure packages were composed by adding each measure one by one to the model, so each package had one measure more than previous.

The costal savings and investment of each measure was estimated by calculations with data from project documentation and energy audits, and the experience of the authors of this study. The energy price has been taken from energy invoices in the years 2017-2018 as $0.031 € / \mathrm{kWh}$ and $0.072 € / \mathrm{kWh}$, respectively, natural gas and electricity.

\section{Results and discussion}

Specific energy use for heating and electricity of the base model has brought out in Figure 5. The calculation of real use resulted the energy use of $113 \mathrm{kWh} / \mathrm{m}^{2}$ and $75 \mathrm{kWh} / \mathrm{m}^{2}$, respectively, for heating and electricity. This achieves the PE of $263 \mathrm{kWh} / \mathrm{m}^{2}$. The calculation of standard use gives the heating energy $89 \mathrm{kWh} / \mathrm{m}^{2}$ and electricity energy $56 \mathrm{kWh} / \mathrm{m}^{2}$ that resulted PE 201 $\mathrm{kWh} / \mathrm{m}^{2}$ (D-level).

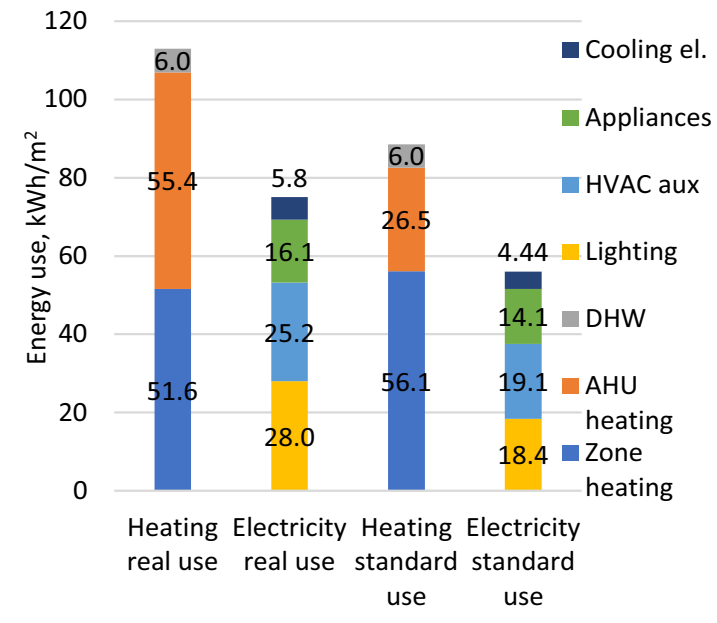

Figure 5. Heating and electricity use of the base model

Table 5. Individual measures implemented in the base model (the sequence is according to the highest saving in primary energy)

\begin{tabular}{|c|c|c|c|c|c|c|c|c|c|c|c|}
\hline \multirow{2}{*}{ No } & \multirow{2}{*}{ Measure description } & \multicolumn{2}{|c|}{ Parameters } & \multicolumn{2}{|c|}{$\begin{array}{l}\text { Delivered energy } \\
\text { savings } \mathrm{kWh} / \mathrm{m}^{2}\end{array}$} & \multicolumn{2}{|c|}{$\begin{array}{l}\text { Annual costal } \\
\text { savings, } € / \mathrm{m}^{2}\end{array}$} & \multirow{2}{*}{$\begin{array}{c}\text { Invest- } \\
\text { ment, } \\
€ / \mathrm{m}^{2}\end{array}$} & \multirow{2}{*}{$\begin{array}{c}\text { Saved } \\
\mathrm{PE} \\
\mathrm{kWh} / \mathrm{m}^{2}\end{array}$} & \multirow{2}{*}{$\begin{array}{l}€ \text { per } \\
\text { saved } \\
\mathrm{PE} \\
€ / \mathrm{kWh}\end{array}$} & \multirow{2}{*}{$\begin{array}{l}\text { Pay- } \\
\text { back } \\
\text { time, } y\end{array}$} \\
\hline & & Base model & After & Electr. & Heat. & Electr. & Heat. & & & & \\
\hline 1 & Improving the lighting & $\begin{array}{c}\text { In trade area } 12 \mathrm{~W} / \mathrm{m}^{2}, \\
\text { office } 10 \mathrm{~W} / \mathrm{m}^{2}\end{array}$ & $\begin{array}{c}\text { In trade area } 12 \mathrm{~W} / \mathrm{m}^{2} \text {, in } \\
\text { office } 6 \mathrm{~W} / \mathrm{m}^{2}\end{array}$ & 11.4 & -4.45 & 0.82 & -0.14 & 8.52 & 18.3 & 0.47 & 12.5 \\
\hline 2 & $\begin{array}{l}\text { Improvement of AHU } \\
\text { fans SFP }\end{array}$ & $\begin{array}{c}\mathrm{SFP}=1.098-1.93 \\
\mathrm{~kW} /\left(\mathrm{m}^{3} / \mathrm{s}\right)\end{array}$ & $\mathrm{SFP}=1-1.7 \mathrm{~kW} /\left(\mathrm{m}^{3} / \mathrm{s}\right)$ & 6.25 & 0.01 & 0.45 & 0.00 & 20.0 & 12.5 & 1.60 & 44.4 \\
\hline 3 & $\begin{array}{c}\text { Improvement of } \mathrm{AHU} \\
\text { heat exchanger }\end{array}$ & $\begin{array}{c}\text { Efficiency: rotated hex. } \\
70 \% \text {; coil hex. } 40 \%\end{array}$ & $\begin{array}{c}\text { Efficiency: rotated hex. } \\
80 \% \text {; coil hex. } 60 \%\end{array}$ & 0.08 & 9.74 & 0.01 & 0.30 & 20.0 & 9.91 & 2.02 & 65.0 \\
\hline 4 & $\begin{array}{l}\text { Adding the cooling effect } \\
\text { to AHU heat exchanger }\end{array}$ & $\begin{array}{c}\text { Heat exchanger is not } \\
\text { working between } 14 \text { May } \\
\text { and } 31 \text { August }\end{array}$ & $\begin{array}{c}\text { Heat exchanger is working } \\
\text { all the time }\end{array}$ & 0.11 & 6.92 & 0.01 & 0.21 & 4.0 & 7.13 & 0.56 & 18.0 \\
\hline 5 & \begin{tabular}{|c|} 
Change of canteens AHU \\
ventilation control
\end{tabular} & CAV & $\begin{array}{l}\text { VAV with } \mathrm{CO}_{2} \text { control and } \\
\text { setpoints min } 700, \max 800\end{array}$ & 1.50 & 4.15 & 0.11 & 0.13 & 4.0 & 7.16 & 0.56 & 16.9 \\
\hline 6 & \begin{tabular}{|c|} 
Changing the windows \\
from 2-layer to 3 -layer \\
windows with better sun \\
protection
\end{tabular} & $\begin{array}{c}\text { Pilkington Suncool 66/33 } \\
\text { (6C(66)-15Ar-4): } \\
\text { g0.36, T0.33, } \mathrm{T}_{\text {vis }} 0.66 \\
\mathrm{U} 1.1 \\
\end{array}$ & $\begin{array}{l}\text { Pilkington Suncool 40/22 } \\
(6 \mathrm{C}(40)-15 \mathrm{Ar}-4-15 \mathrm{Ar}-\mathrm{S}(3) 4) \text { : } \\
\mathrm{g} 0.2, \mathrm{~T} 0.17, \mathrm{~T}_{\mathrm{vis}} 0.36, \mathrm{U} 0.6\end{array}$ & 0.75 & 3.84 & 0.05 & 0.12 & 12.0 & 5.34 & 2.24 & 69.3 \\
\hline 7 & \begin{tabular}{|c|}
$\begin{array}{c}\text { Night setback of indoor } \\
\text { temperature }\end{array}$ \\
\end{tabular} & constant $21^{\circ} \mathrm{C}$ & $\begin{array}{l}\text { 6-20:00 set to } 21^{\circ} \mathrm{C} ; \\
\text { Other time set to } 19^{\circ} \mathrm{C}\end{array}$ & 0.20 & 4.78 & 0.01 & 0.15 & 0.06 & 5.18 & 0.01 & 0.39 \\
\hline 8 & $\begin{array}{c}\text { Sun protection film } \\
\text { improving the windows } \\
\text { shading }\end{array}$ & $\begin{array}{l}\text { Shading parameters: } \\
\text { g0.36, T0.33 }\end{array}$ & $\begin{array}{l}\text { Shading parameters: } \\
\text { g0.20, T0.13 }\end{array}$ & 0.73 & -2.41 & 0.05 & -0.07 & 6.33 & -0.94 & -6.70 & NA \\
\hline 9 & $\begin{array}{l}\text { Improvement of free } \\
\text { cooling function }{ }^{1}\end{array}$ & $\begin{array}{c}\text { Tamb }<11^{\circ} \mathrm{C} \\
\text { Tsupply }=18^{\circ} \mathrm{C} ; \\
\text { Tamb }>11^{\circ} \mathrm{C} \\
\text { Tsupply }=16^{\circ} \mathrm{C}\end{array}$ & $\begin{array}{c}\text { Tamb }<15^{\circ} \mathrm{C} \\
\text { Tsupply }=18^{\circ} \mathrm{C} \\
\text { Tamb }>15^{\circ} \mathrm{C} \\
\text { Tsupply }=16^{\circ} \mathrm{C}\end{array}$ & -0.33 & -1.14 & -0.02 & -0.04 & 0.06 & -1.80 & -0.04 & NA \\
\hline 10 & PV panels installation & No PV system & $\begin{array}{c}\text { Installation of } 230 \text { panels } \\
\text { with system power } 69 \mathrm{~kW}\end{array}$ & 3.28 & 0 & 0.24 & 0.00 & 5.62 & 6.6 & 0.86 & 23.8 \\
\hline
\end{tabular}

\footnotetext{
${ }^{1}$ Setpoint of supply air temperature $\left(\mathrm{T}_{\text {supply }}\right)$ was adjusted by ambient temperature $\left(\mathrm{T}_{\mathrm{amb}}\right)$
} 


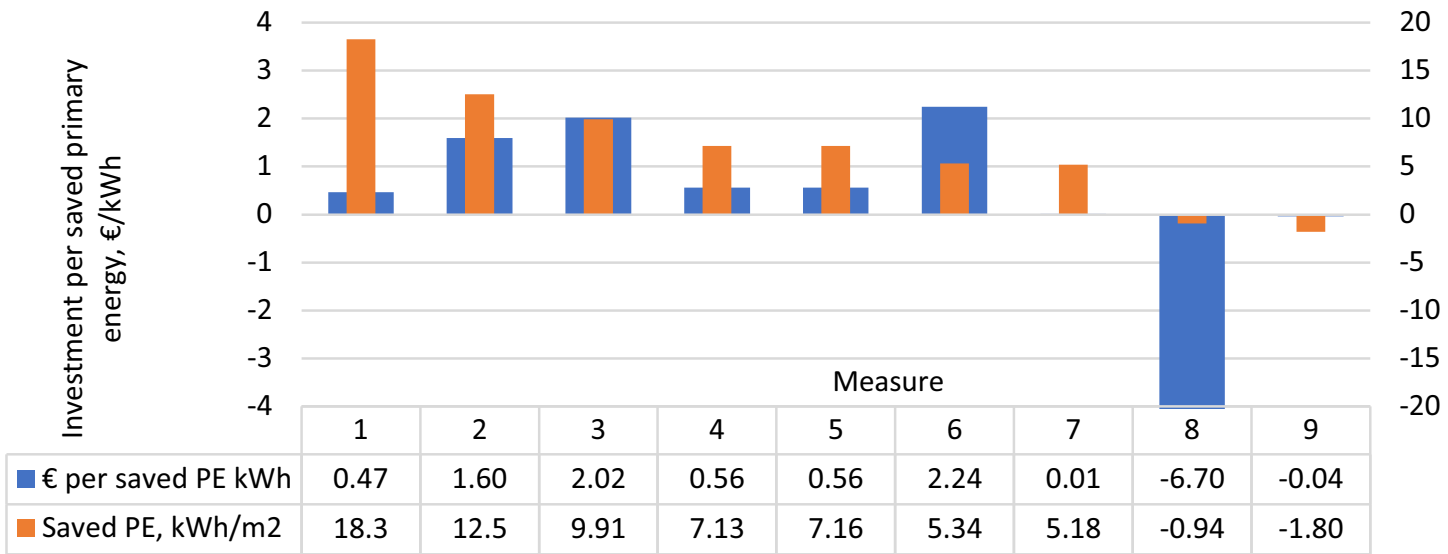

Figure 6. The investment and saved primary energy of individual measures

Furthermore, several renovation measures in Table 5 were implemented in the base model and the energy savings were identified. The highest saving in primary energy was achieved by replacing the fluorescent lighting with LED $-18.6 \mathrm{kWh} / \mathrm{m}^{2}$ annually. That was also the cheapest measure with $0.47 \mathrm{€} / \mathrm{kWh}$ saved primary energy and the shortest 12.5 -year payback time. Measures 2 and 3 have bigger investment, because the improvement of AHU fans or heat exchanger separately still needs a replacement of the entire air handling unit that costs about $20 € / \mathrm{m}^{2}$. The payback time will be 26 years, if the measures are made together (AHU replaced with unit with better fans SFP and heat exchanger temperature efficiency). From Figure 6 we can see that measures like sun protection film and improvement of free cooling function were less worth measures and in further analyses they are not involved. The installation of the PV-panel system was an additional measure to achieve NZEB level.

The energy simulations were done with the base model and models with the four following packages (pack.) with similar payback time:

- Package 1 - measures 1-4: pay-back time 32 years

- Package 2 - measures 1-5: pay-back time 30 years

- Package 3-measures 1-6: pay-back time 34 years

- Package 4-measures 1-7: pay-back time 32 years PV-panel (measure no 10) was later added to all packages. Previously mentioned, the base model had standard use PE $200 \mathrm{kWh} / \mathrm{m}^{2}$ and EPC label D. Package 1 improved the electricity and heating energy considerably (Figure 7-Figure 8) - respectively, 19 $\mathrm{kWh} / \mathrm{m}^{2}$ and $8.4 \mathrm{kWh} / \mathrm{m}^{2}$. However, the standard use PE is $173 \mathrm{kWh} / \mathrm{m}^{2}$ that stays in EPC D-level. Further packages did not improve the electricity performance, but reduced the heating energy use considerably. Adding measure 5, the canteen AHU control with $\mathrm{CO}_{2}$ sensors (package 2) reduced the heating energy for 7.2 $\mathrm{kWh} / \mathrm{m}^{2}$ and resulted the standard use PE $165 \mathrm{kWh} / \mathrm{m}^{2}$, that is close to NZEB level. With package 3, after replacing the windows, the heating energy reduces for $3.5 \mathrm{kWh} / \mathrm{m}^{2}$ and resulted in NZEB level with standard $\mathrm{PE}$ use $160 \mathrm{kWh} / \mathrm{m}^{2}$. Using the night setback of indoor temperature in addition to previous measures (package 4) saved the heating energy for $4.3 \mathrm{kWh} / \mathrm{m}^{2}$ and gave good PE use even without PV-panels - $163 \mathrm{kWh} / \mathrm{m}^{2}$.
Nevertheless, to achieve NZEB major renovation, the installation of PV panel system is essential.

The payback time of individual measures is high and will be over 40 years for half of measures. However, if measures are made as packages, the payback time is smaller, but still in between 30-34 years. Furthermore, replacing the window change measure with the night setback measure will reduce the investment of package 3 , but the pay-back time will be still about 28 years.

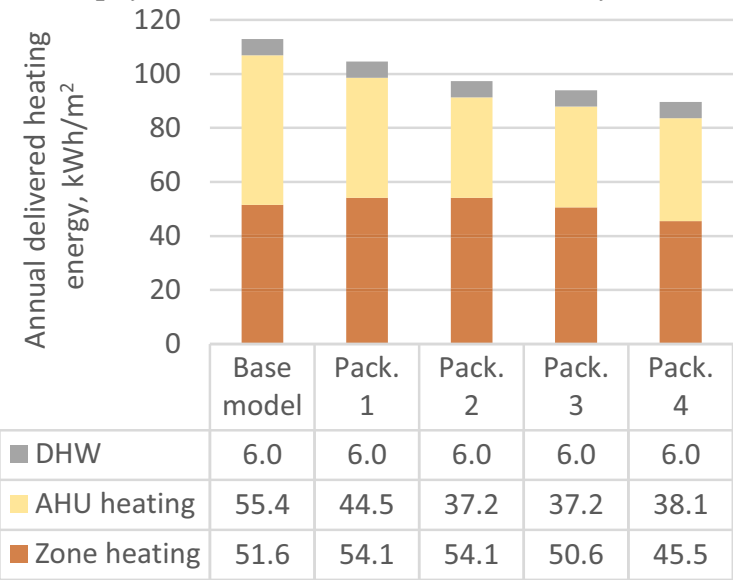

Figure 7. Annual delivered real heating energy for the base model and models with different renovation packages

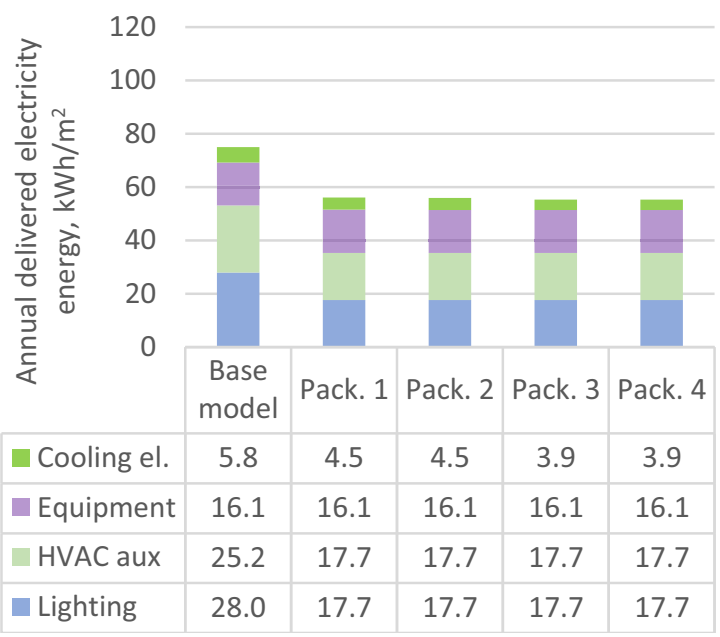

Figure 8. Annual delivered real electricity energy for the base model and models with different renovation packages 


\section{Conclusion}

Analyse of energy efficiency and cost-optimal measures for non-residential building renovation is essential to achieve the goal and decrease greenhouse gas emissions. Therefore, this study focused on energy performance and renovation measures, citing one larger office building as an example. The measured energy consumption, the calibration method of energy simulation with energy consumption of the existing office building, and identification of energy renovation measures were the tools to discover the improvement of the energy performance to NZEB level of major renovation.

The cheapest measure, changing the lighting improved the electricity energy performance significantly and therefore, saved the primary energy for $18.6 \mathrm{kWh} / \mathrm{m}^{2}$. In general, the majority of measures were with good primary energy saving $\left(5-18 \mathrm{kWh} / \mathrm{m}^{2}\right)$, but at the same time with long payback time for real estate companies - over 16 years, and even will reach over 60 years. Using the measures together in renovation packages reduced the payback time to 30 years, that is still not suitable for real estate companies.

Authors found that replacing fluorescent lighting to LED, upgrading the AHU with a better performance unit, and improving the automatics, using night setback for heating and replacing windows will result the primary energy use close to the NZEB as $163 \mathrm{kWh} / \mathrm{m}^{2}$. However, to reach this goal, the $69 \mathrm{~kW}$ photovoltaic panel system is needed.

The replacing of the windows in an office building is a big investment measure and will be under serious consideration, is it needed or not. Calculations show that replacing the window change measure with the night setback measure will result the PE use $161 \mathrm{kWh} / \mathrm{m}^{2}$, that is almost NZEB level, but it needs further investigation with some more case studies.

The limitation of this study is the calibration method, as the measured data has been weather normalized, but the simulation were done with test reference year. Further studies need to be done to investigate the impact of this difference and to develop the calibration methodology.

This research was supported by the Estonian Centre of Excellence in Zero Energy and Resource Efficient Smart Buildings and Districts, ZEBE (grant 2014-2020.4.01.150016) funded by the European Regional Development Fund, by the European Commission through the H2020 project Finest Twins (grant No. 856602) and the Estonian Research Council grant (PSG409).

\section{References}

[1] THE EUROPEAN PARLIAMENT AND THE COUNCIL, "DIRECTIVE (EU) 2018/844," 2018. doi: 10.1007/3-540-47891-4_10.

[2] The European Comission, "Directive 2012/27/EU of the European Parliament and of the Council of 25 October 2012 on energy efficiency," no. November 2010, pp. 1-56, 2012.

[3] European Union, "Directive 2010/31/EU of the European Parliament and of the Council of 19 May 2010 on the energy performance of buildings," 2010.

[4] BPIE, Europe's buildings under the microscope, Buildings Performance Institute Europe. 2011.

[5] M. Hinnells, "Technologies to achieve demand reduction and microgeneration in buildings," Energy Policy, vol. 36, no. 12, pp. 4427-4433, 2008, doi: 10.1016/j.enpol.2008.09.029.

[6] Estonian Government's Ordinance, "Minimum requirements for energy audit - (Energiaauditi miinimumnõuded), 2016.

https://www.riigiteataja.ee/akt/123122016003? leiaKehtiv (accessed Dec. 15, 2020).

[7] ISO, “EN ISO 52000-1:2017," 2017.

[8] Estonian Government's Ordinance, "Methodology for calculating the energy performance of buildings," Riigi Teataja, 2019. https://www.riigiteataja.ee/en/eli/52010201400 2/consolide (accessed Aug. 20, 2020).

[9] H. Kuivjõgi, A. Uutar, K. Kuusk, M. Thalfeldt, and J. Kurnitski, "Market based renovation solutions in non-residential buildings - why commercial buildings are not renovated to NZEB," 2021.

[10] SINTEF, “LECO - Energibruk i fem kontorbygg i Norge (LECO - Energy use in five office buildings in Norway)," Oslo, 2009.

[11] Ministry of Economics, "Long-Term Strategy for Building Renovation (Estonia)," 2020. [Online]. Available:

https://ec.europa.eu/energy/sites/ener/files/doc uments/2014_article4_en_latvia.pdf.

[12] P. Bannister, C. Bloomfield, and H. Chen, "Empirical prediction of office building lift energy consumption," Proc. Build. Simul. 2011 12th Conf. Int. Build. Perform. Simul. Assoc., pp. 2635-2642, 2011.

[13] T. Kalamees and J. Kurnitski, "Estonian test reference year for energy calculations," no. January, pp. 40-58, 2006.

[14] ANSI/ASHRAE, "ASHRAE Guideline 142002 Measurement of Energy and Demand Savings," Ashrae, vol. 8400, p. 170, 2002. 


\section{Appendix 1}

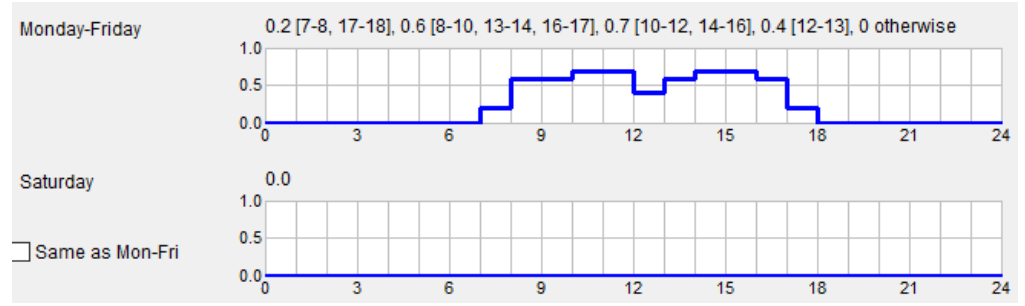

Figure 9. Schedule for occupants, equipment and lighting

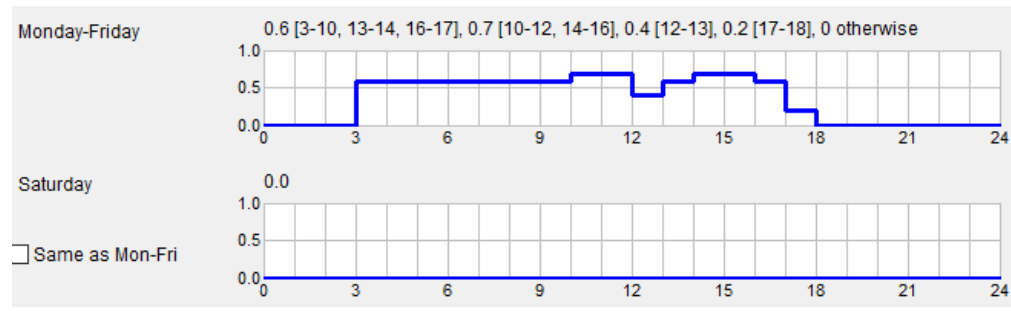

Figure 10. Schedule for C-building occupants, equipment and offices

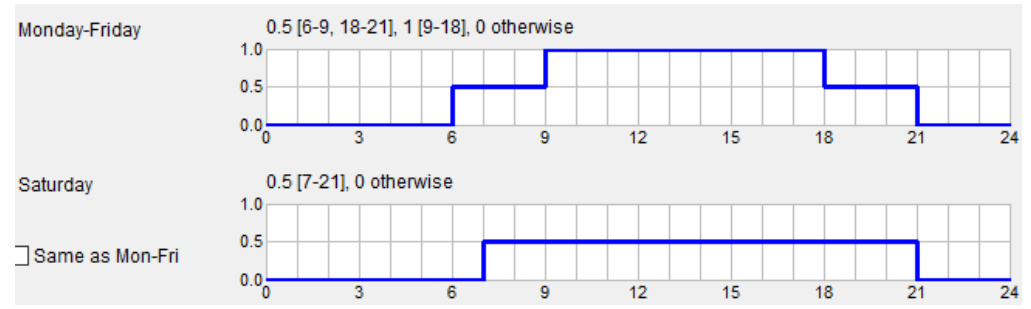

Figure 11. Schedule for AHU1

Monday-Friday

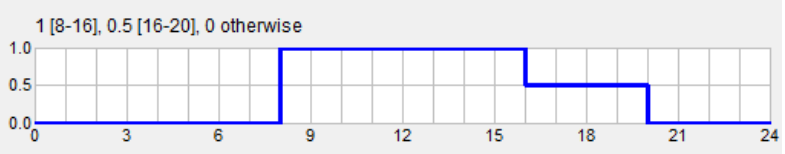

Saturday

] Same as Mon-Fri

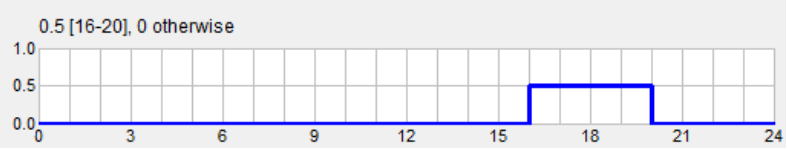

Figure 12. Schedule for AHU2 (canteen)

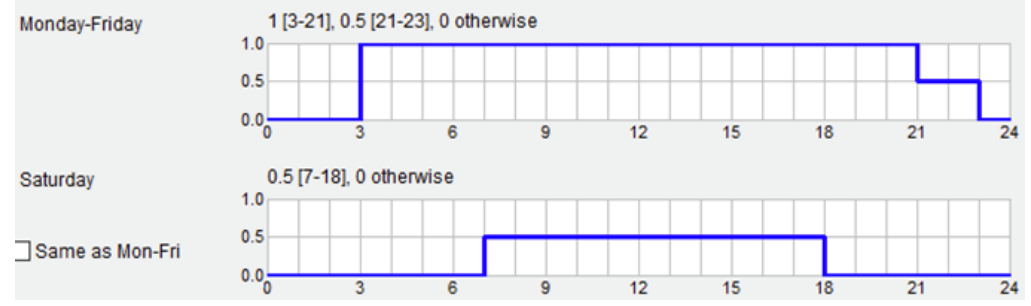

Figure 13. Schedule for AHU3 (C-building)

Monday-Friday

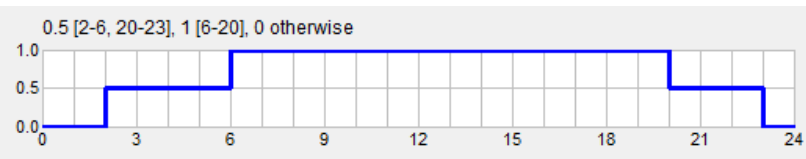

Saturday

$\sqsupset$ Same as Mon-Fri

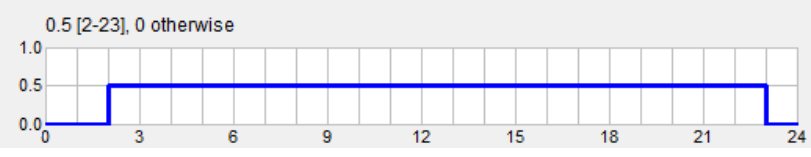

Figure 14. Schedule for AHU4 